\title{
Practice and Enlightenment of Cooperation on PTRA for Internship in A\&F Economics \& Management-A Case of Heilongjiang Bayi Agricultural University
}

\author{
Shuguo Yang*, Huiqin Zhang \\ College of Economics \& Management, Heilongjiang Bayi Agricultural University, Daqing, China \\ Email: *rhwysg@163.com
}

How to cite this paper: Yang, S. G., \& Zhang, H. Q. (2019). Practice and Enlightenment of Cooperation on PTRA for Internship in A\&F Economics \& Management-A Case of Heilongjiang Bayi Agricultural University. Creative Education, 10, 655-666.

https://doi.org/10.4236/ce.2019.104048

Received: January 27, 2019

Accepted: April 1, 2019

Published: April 4, 2019

Copyright $\odot 2019$ by author(s) and Scientific Research Publishing Inc. This work is licensed under the Creative Commons Attribution International License (CC BY 4.0).

http://creativecommons.org/licenses/by/4.0/

\section{(c) (i) Open Access}

\begin{abstract}
Internship in major, internship in graduation and thesis are essential practical processes in A\&F Economics \& Management program for undergraduate students. In view of the problems in Internship in A\&F Economics \& Management, such as insufficient funding, unstable internship place, unsatisfactory effect, and so on, this paper discussed so many years' practice of PTRA for internship in Heilongjiang Bayi Agricultural University using the method of case analysis. We concluded that PTRA for Internship in A\&F Economics \& Management may improve professional knowledge level and comprehensive practical ability of students, enhance professional and practical ability of teachers, overcome effectively the problem of insufficient internship funding, promote the reputation of the university and the major, which may be used as a reference for the internship in A\&F Economics \& Management in other agricultural colleges and universities.
\end{abstract}

\section{Keywords}

Agricultural \& Forestry Economics \& Management (A\&F Economics \& Management), Production, Teaching, Research and Application (PTRA), Practical Teaching

\section{Introduction}

With the reform and development of higher education, more and more universities began to pay more attention to practical teaching and the reform of teaching began to run deeply. Internship in major, internship in graduation and thesis are 
the essential practical processes in A\&F Economics \& Management. It is necessary to improve the ability of theory and practice for undergraduate students through integrating the basic theory, professional knowledge and practical application. It is an important mission for the major in agricultural colleges and universities, and also an important part of agricultural education reform to train high quality applied talents facing production practice to serve for agriculture and rural economy in national economic development. Heilongjiang Bayi Agricultural University has summarized some effective methods, and also got some enlightenment in the practical exploration through integrating internship in major, internship in graduation and thesis and following by the principle of PTRA for practical teaching in so many years.

\section{Challenges of Internship in A\&F Economics \& Management}

In order to adapt to the development of higher education reform, the proportion of practical teaching has been increased in A\&F Economics \& Management in agricultural university. For example, the credits for practical teaching accounted for $19.84 \%$ of the total credits in A\&F Economics \& Management program in Heilongjiang Bayi Agricultural University in 2014 (18.1\% in and Northwest A\&F University and $14.38 \%$ in China Agricultural University) and the centralized practical teaching lasted 68 weeks. However, the practical teaching is often mere formality and fails to achieve the expected results due to paying no attention to it, lack of funding and willing of internship bases, and so on (He, 2011). It is difficult to carry out the internship in the major and in graduation in actual performance. The major mismatches the post in the internship bases selected by students themselves. It is not perfect enough in the infrastructure and project implementation of the internship bases cooperated with the university. In a word, it has become a serious problem to A\&F Economic \& Management to facing the difficulty of internship and has gradually affected the employment of students and enrollment of universities. The problems are as follow just for A\&F Economic \& Management in Heilongjiang Bayi Agricultural University.

\subsection{Internship Funding Has Been Reduced Year after Year}

Internship funding is important to guarantee practice for undergraduate students. But lack of funding and reduction in successive years have become the biggest barrier to reduce the expenditure on internship year after year which leads to in A\&F Economics \& Management in Heilongjiang Bayi Agricultural University. In the past five years, the total expenditure on internship has been reduced from 41 thousand yuan in 2013 to 25 thousand yuan in 2016, which included the expense of instructors, and the expenditure for per student has dropped from 630 yuan in 2014 to 336 yuan in 2017, as shown in Table 1.

The most basic requirement of the internship in the major is to carry out household survey in rural area for undergraduate students, which needs large 
Table 1. Expenditure on internship in A\&F economics \& management in Heilongiiang Bayi Agricultural University in the past six years.

\begin{tabular}{ccccc}
\hline year & $\begin{array}{c}\text { Total Expenditure } \\
\text { (Yuan) }\end{array}$ & $\begin{array}{c}\text { \# of } \\
\text { Students }\end{array}$ & $\begin{array}{c}\text { Average Expenditure } \\
\text { (Yuan per student) }\end{array}$ & $\begin{array}{c}\text { \# of } \\
\text { Instructors }\end{array}$ \\
\hline 2013 & 41,000 & 77 & 532 & 4 \\
2014 & 34,010 & 54 & 630 & 4 \\
2015 & 31,013 & 59 & 529 & 5 \\
2016 & 25,632 & 69 & 371 & 3 \\
2017 & 42,991 & 128 & 336 & 4 \\
2018 & 37,674 & 85 & 443 & 2 \\
\hline
\end{tabular}

Source: Department of A\&F of Economics \& Management, Heilongjiang Bayi Agricultural University.

expenditure. But because the actual expenditure of the internship could not be met by the funding of the school, it needed instructors and students to pay part of the expense or relied on the help from some internship companies in the past, which affected the enthusiasm of instructors and students and increased the burden of the internship companies.

\subsection{Internship Effect Can't Be Guaranteed}

According to the A\&F Economics \& Management program, the internship lasts six weeks (30 days). But because the internship funding is insufficient and the internship supervision is exactitude, the internship period is less than 30 days. During the internship period, most of students go to the enterprises around the school to have a look and there is no substantive content. The effect of internship cannot be guaranteed by time.

\subsection{Internship Place Is Instable}

For students of A\&F Economic \& Management, it is important to establish stable off-campus internship bases, which guarantees and helps students to get in touch with the society quickly, and transform the theoretical knowledge they have learned into practical application ability, and better understand and analyze the development of agricultural economy. In recent years, the administrators have tried to sign the agreement with different enterprises and institutions, but the contracts often do not maintain a long-term, that is, students come here for an internship this year, but do not sure where they are going next year. On the one hand, it consumes the energy of relevant personnel to search for internship bases every year. On the other hand, students' internship bases are precarious, which has a great impact on the quality of internship.

\section{Design and Implementation of PTRA for Internship in A\&F Economics \& Management}

\subsection{Design of PTRA for Internship in A\&F Economics \& Management}

\subsubsection{Establish Stable Internship Bases Based on PTRA}

Long-term stable internship base is an important place to train the students in 
A\&F Economic \& Management practical ability, scientific research ability, innovative consciousness and innovative ability. It is also an educational platform to strengthen major and society exchange and cooperation, to carry out cooperative education of PTRA, and to expand the training channels of A\&F Economic \& Management.

Firstly, the main factors considered are conforming to the major, helping arrange the accommodation for instructors and students, holding more than 8 students, attaching importance to students' internship and meeting the requirements of the other internship conditions when Heilongjiang Bayi Agricultural University chooses the internship bases. Secondly, in order to ensure the integrity and coherence of teaching, both on-campus and off-campus internship bases are built at the same time. The construction of on-campus internship base breaks through the old mode of perceptual knowledge and skill training, and makes it a practical teaching place in and off school for comprehensive training in the environment of modem enterprises. In 2014, the College of Economics \& Management and the College of Accounting jointly established the VBSE (Virtual Business Social Environment) laboratory, mainly used for students' practical training. While the off-campus internship bases were mainly used to PTRA places based on the long-term stable principles, mutual benefit and prominent characteristics. The youngest internship bases are over three years. As shown in Table 2.

\subsubsection{Draw Up a Plan of Internship in A\&F Economics \& Management} The dean of department of A\&F Economic \& Management in Heilongjiang Bayi Agricultural University draws up an internship plan for junior students at the beginning of spring semester based on the major program, internship funding and requirements of internship. The plan includes the objectives and requirements of internship, instructors, the internship bases and arrangement, the responsibilities of the instructors and the requirements for students, assessment of internship outcomes, and the internship funding plan. The internship process includes cognitive internship, on-campus internship and off-campus internship. In the process of drawing up internship plan, the emphasis is on the selection and arrangement of the internship places. The internship places are selected from those signed the agreement. At the same time, according to the internship objectives, the internship funding and the current situation of the internship places, internship content and time are arranged and internship are carried out scientifically and orderly.

\subsubsection{Integrate Internship in the Major, Internship in Graduation and Thesis}

We will take into account the section of internship in the major, in graduation and thesis before the internship is carried out in order to achieve the combination of PTRA. On the one hand, the content of internship in the major is closely related to students' thesis, especially in the investigation section in the 
Table 2. Off-campus internship bases.

\begin{tabular}{|c|c|c|c|c|}
\hline Number & Internship bases & Address & $\begin{array}{l}\text { Established } \\
\text { Year }\end{array}$ & $\begin{array}{l}\text { Capacity (\# } \\
\text { of Students) }\end{array}$ \\
\hline 1 & $\begin{array}{l}\text { Bureau of Housing and } \\
\text { Urban-Rural Planning and } \\
\text { Construction Honggang } \\
\text { District, Daqing }\end{array}$ & $\begin{array}{l}\text { Honggang District } \\
\text { Daqing City } \\
\text { Heilongjiang }\end{array}$ & 2011 & 10 \\
\hline 2 & $\begin{array}{l}\text { Weishan Farm, Beidahuang } \\
\text { Agricultural Reclamation } \\
\text { Group Corporation }\end{array}$ & $\begin{array}{l}\text { Wudalianchi City } \\
\text { Heilongjiang }\end{array}$ & 2012 & 15 \\
\hline 3 & $\begin{array}{l}\text { Daqing Yulu Agricultural } \\
\text { Science and Technology } \\
\text { Development Co., Ltd. }\end{array}$ & $\begin{array}{l}\text { Tiedong village Longfeng } \\
\text { District Daing City }\end{array}$ & 2013 & 60 \\
\hline 4 & $\begin{array}{l}\text { Yi'an Heidi House Potato } \\
\text { Specialty Cooperative }\end{array}$ & $\begin{array}{l}\text { Yi'an county } \\
\text { Heilongjiang }\end{array}$ & 2014 & 10 \\
\hline 5 & $\begin{array}{c}\text { Hailun Farm, Heilongjiang } \\
\text { Beidahuang Agricultural } \\
\text { Reclamation Group Corporation }\end{array}$ & $\begin{array}{l}\text { Hailun City } \\
\text { Heilongjiang }\end{array}$ & 2014 & 20 \\
\hline 6 & $\begin{array}{l}\text { Yinlonghe Farm, Heilongjiang } \\
\text { Beidahuang Agricultural } \\
\text { Reclamation Group Corporation }\end{array}$ & $\begin{array}{l}\text { Wudalianchi City } \\
\text { Heilongjiang }\end{array}$ & 2015 & 15 \\
\hline 7 & $\begin{array}{l}\text { ErLongshan Farm, Heilongjiang } \\
\text { Beidahuang Agricultural } \\
\text { Reclamation Group Corporation }\end{array}$ & $\begin{array}{l}\text { Bei'an City } \\
\text { Heilongjiang }\end{array}$ & 2015 & 15 \\
\hline 8 & $\begin{array}{l}\text { Hongxing Farm, Heilongjiang } \\
\text { Beidahuang Agricultural } \\
\text { Reclamation Group Corporation }\end{array}$ & $\begin{array}{l}\text { Bei'an City } \\
\text { Heilongjiang }\end{array}$ & 2015 & 15 \\
\hline 9 & $\begin{array}{l}\text { Heilongjiang Litao Potato } \\
\text { Specialty Cooperative }\end{array}$ & $\begin{array}{l}\text { Zhongxin village Shuanghe } \\
\text { Town Keshan county }\end{array}$ & 2015 & 10 \\
\hline 10 & $\begin{array}{c}\text { Keshan Kunfeng Modern } \\
\text { Agricultural Machinery } \\
\text { Specialty Cooperative }\end{array}$ & $\begin{array}{l}\text { Zhongxin village Shuanghe } \\
\text { Town Keshan county }\end{array}$ & 2015 & 10 \\
\hline 11 & $\begin{array}{l}\text { Nehe School of Vocational and } \\
\text { Technical Education Center }\end{array}$ & $\begin{array}{c}\text { West Nemo highway } \\
\text { Tongjiang Road Nehe City }\end{array}$ & 2015 & 30 \\
\hline 12 & $\begin{array}{l}\text { Nehe Jinlong Economic Crop } \\
\text { Specialty Cooperative }\end{array}$ & Lumin Village Nehe City & 2015 & 10 \\
\hline 13 & $\begin{array}{l}\text { Nehe Duojun Rice Planting } \\
\text { Specialty Cooperative }\end{array}$ & $\begin{array}{l}\text { Quansheng Village } \\
\text { Nehe City }\end{array}$ & 2015 & 10 \\
\hline 14 & $\begin{array}{l}\text { Nehe Variety Crops } \\
\text { Specialty Cooperative }\end{array}$ & $\begin{array}{c}\text { Quansheng } \\
\text { Village Nehe City }\end{array}$ & 2015 & 10 \\
\hline
\end{tabular}

Source: Department of A\&F of Economics \& Management, Heilongjiang Bayi Agricultural University.

off-campus internship places, which is the content of thesis to be completed. On the other hand, internship in the major is combined with that in graduation. In the process of internship in the major, students may practice on duty and they may go to the internship places to complete their internship in graduation when they are senior if the two sides (i.e. companies and students) agree and approve, 
and students can also complete their thesis in the internship places.

\subsection{Implementation of PTRA for the Internship in A\&F Economics \& Management}

In terms of the design of the internship in $A \& F$ Economics \& Management, the internship process will be introduced through taking the junior students in the sixth semester in 2015 as an example.

\subsubsection{Arrange and Organize the Internship}

Cooperative Economic area was separated from A\&F Economic \& Management in the first half year of 2014. So we not only considered students' major and area, but also considered the combination of internship in the major, internship in graduation and thesis, that is, the combination of PTRA in different section. The internship was implemented according to the following steps.

The first step was to choose internship bases. The dean selected the internship places from off-campus internship bases in terms of student' area, content of internship and accommodation of internship places. She Chose VBSE Lab as a training place, Daqing Yulu Agricultural Science and Technology Development Co., Ltd. as a cognitive place, three farms in Bei'an city as off-campus internship places for non-cooperative economic students, and three specialty cooperative in Nehe city and Nehe School of Vocational and Technical Education Center for cooperative economic students.

The second step was to identify the instructor for graduation thesis. After both way free choice between students and professional teachers of the department, the thesis instructor was finally determined. There were 59 junior students, of which 22 came from cooperative economy area and 12 professional teachers for their choice of which 6 teachers in cooperative economy area. Finally, 4 - 6 students were guided by each teacher.

The third step was to determine the topic of graduation thesis and design the questionnaire. The topic was initially agreed between students and instructors. It may come from the scientific research project of instructors, and also be an investigation to some fields and businesses of internship places or some agricultural development issues. After making sure the topic, students should complete the design of their questionnaires under the guidance of instructors in one week.

The fourth step was to group the students. Students were grouped into different internship places according to the topics of thesis and the investigated contents, which were agreed upon by students and instructors. As shown in Table 3.

\subsubsection{Implement the Internship Based on PTRA}

According to the A\&F Economic \& Management program, the internship for junior students would last for 4 weeks in the sixth semester in 2015. The contents of the internship included training simulation, cognitive practice and investigation.

Training simulation was divided into two parts. Firstly, all the students were 
Table 3. Groups of the students.

\begin{tabular}{|c|c|c|c|c|c|}
\hline Internship Place & $\begin{array}{c}\text { \# of } \\
\text { Students }\end{array}$ & $\begin{array}{c}\text { \# of } \\
\text { Instructors }\end{array}$ & Participant & Duration & Content \\
\hline $\begin{array}{c}\text { VBSE Lab Heilongjiang } \\
\text { Bayi Agricultural } \\
\text { University }\end{array}$ & 59 & 2 & all & 1 week & $\begin{array}{c}\text { Training } \\
\text { Simulation }\end{array}$ \\
\hline $\begin{array}{l}\text { Daqing Yulu Agricultural } \\
\text { Science and Technology } \\
\text { Development Co., Ltd. }\end{array}$ & 59 & 1 & all & 1 week & $\begin{array}{l}\text { cognitive } \\
\text { practice }\end{array}$ \\
\hline Yinlonghe Farm & 13 & 1 & $\mathrm{~N}^{1}$ & 2 weeks & Investigation \\
\hline ErLongshan Farm & 12 & 1 & $\mathrm{C}^{2}$ & 2 weeks & Investigation \\
\hline Hongxing Farm & 12 & 1 & $\mathrm{~N}^{1}$ & 2 weeks & Investigation \\
\hline $\begin{array}{c}\text { Nehe School of } \\
\text { Vocational and Technical } \\
\text { Education Center }\end{array}$ & 22 & 2 & $\mathrm{C}^{2}$ & 1 week & $\begin{array}{l}\text { Training } \\
\text { Simulation }\end{array}$ \\
\hline $\begin{array}{l}\text { Nehe Jinlong Economic } \\
\text { Crop Specialty Cooperative }\end{array}$ & 9 & 1 & Part of $C^{2}$ & 1 week & Investigation \\
\hline $\begin{array}{c}\text { Nehe Duojun Rice Planting } \\
\text { Specialty Cooperative } \\
\text { Nehe Variety Crops } \\
\text { Specialty Cooperative }\end{array}$ & 6 & 1 & Part of $C^{2}$ & 1 week & Investigation \\
\hline
\end{tabular}

${ }^{1}$ Students from Non-cooperative economic area; ${ }^{2}$ Students from cooperative economic area; Source: Department of A\&F of Economics \& Management, Heilongjiang Bayi Agricultural University.

required to enter the VBSE lab to complete training simulation in the first week. In order to ensure learning effectiveness, we selected one trained teacher from the department and hired a professional lecturer from UFIDA Software Co. Ltd to guide students. The lecturer of UFIDA Software Co. Ltd should tailor the relevant business for the students according to the specialty characteristics of A\&F Economic \& Management. The main businesses involved manufacturing, suppliers, customers, logistics companies, accounting firms, international trade companies, bidding companies, chain retail companies and social resources, in which students could experience the operation of commercial society. Secondly, 22 students from cooperative economy entered Nehe School of Vocational and Technical Education Center before entering the cooperative to carry out investigation in the third week. They completed the whole process simulation of cooperative operation through the guidance of two professional teachers from the school and two teachers from the department of A\&F Economic \& Management in the cooperative simulation lab of the school.

The dean organized the students into the agricultural enterprises, Daqing Yulu Agricultural Science and Technology Development Co., Ltd. to carry out the cognitive practice. Firstly, students visited the enterprise to feel modern agricultural enterprises from the overall scale, facilities and environment. Secondly, students comprehensively understood the agricultural production process through on-site explanations by professional and technical personnel of the enterprises. Thirdly, some students worked on regular post in the enterprise, expe- 
rienced the working process in agricultural enterprises to achieve the preliminary combination of PTRA.

The Dean appointed 5 professional teachers to lead the students into farms or cooperatives for investigation from the third week to the fourth week. Besides investigation, the students who entered the specialty cooperatives directly participated in the production process of cooperatives. We took the investigation of 13 students into Yinlonghe Farm as an example to introduce the implementation process of the investigation.

It could be divided into three steps in the basic operating procedures. The first step is that the students had an intuitive feeling and understanding of the farm through understanding the development status of the farm introduced by general manager of Yinlonghe Farm, and visiting the farm, including modern agricultural demonstration zone, grain and oil enterprises and a management area. The second step is that the instructor grouped 13 students according to the their topic area, and connected with the farm authorities to understand the relevant topic. As shown in Table 4. The third step is that students walked into households for interviews in terms of the specific problems that they intended to investigate.

We adopted a management model of "centralized-decentralized-centralized" in the organization and management. The instructor organized 13 students a short meeting on everyday 7:30 am to clarify the research objectives of each student, gave the necessary guidance to the students, and helped the students to contact the farmers. Then, students went out for interviews in all daytime. After dinner, 13 students would be organized to hold an exchange meeting. Everyone would share with others the harvest, experience and difficulties or puzzled of the investigation that very day. Everyone would brainstorm and put forward opinions and suggestions to each other in order to carry out the investigation smoothly and effectively the next day.

Table 4. Topics and relevant departments in Yinlonghe farm.

\begin{tabular}{|c|c|c|}
\hline Topic & \# of Students & Department \\
\hline Livestock & 1 & Department of Livestock \\
\hline The living of residents & 5 & Community \\
\hline Insurance of residents & 2 & $\begin{array}{c}\text { Department of Human } \\
\text { Resources and Social Security }\end{array}$ \\
\hline Construction of small towns & 1 & Planning Office, Community \\
\hline $\begin{array}{l}\text { Production and circulation of } \\
\text { Soybean }\end{array}$ & 2 & Department of Production \\
\hline Agricultural subsidy policy & 2 & $\begin{array}{c}\text { Office of Institutional Policy, } \\
\text { Finance section }\end{array}$ \\
\hline Total & 13 & - \\
\hline
\end{tabular}

Source: Department of A\&F of Economics \& Management, Heilongjiang Bayi Agricultural University. 
In addition to students' investigation, on-the-job practice is also one of the important forms of the internship. For example, 5 students specialized in residents' living were assisting in the Resident Community Assistance to Residential Committee to carry out specific work during the internship, and 2 students specialized in livestock would be directly engaged in internship in graduation in the eighth semester in order to continue to do investigation and thesis.

\section{Effect and Enlightenment of Cooperation on PTRA for Internship in A\&F Economics \& Management}

Practice showed that the PTRA for internship in A\&F Economics \& Management in Heilongjiang Bayi Agricultural University was according with the higher education reform and development and A\&F Economic \& Management training objectives, and had achieved good results. We hope that it may provide a reference for other agricultural colleges and universities.

\subsection{Effect of Cooperation on PTRA for Internship in A\&F Economics \& Management}

In the aspect of internship bases construction, it provided guarantee for cooperation on PTRA for internship through establishing PTRA off-campus internship bases according to the demands and characteristics of the major and area. In the aspect of internship section, we combined internship in the major, internship in graduation and thesis, which made full use of the internship hours, and also made each student's goal more clearly. In the aspect of internship content, it enriched the internship content and broadened the scope of internship from training simulation to cognitive practice, from field investigation to on-the-job practice. In the aspect of internship operation, it the ensured that the practice was carried out in an orderly manner through step-by-step operation from macro to micro and from centralization to decentralization. In the aspect of internship organization and management, we implemented a management model of "centralized-decentralized-centralized" and focused on discussion, which consolidated the results of the internship, and ensured the effectiveness of the internship.

\subsubsection{Improve Professional Knowledge Level and Comprehensive Practical Ability of Students}

The cooperation on PTRA in internship in A\&F Economics \& Management greatly enhanced the consciousness and initiative practice because the practice goals of students were so clear and the sense of responsibility of instructors was so strong. During the process of internship, students obtained direct and indirect practical experience of agricultural production and agribusiness operation and management from managers, professional technicians or workers, which not only deepened the professional knowledge, but also learned the agricultural production knowledge out of school. In addition, the cooperation on PTRA for internship was more effective in training and exercising students' comprehensive 
abilities. For example, the ability of students' language expression and interpersonal skills has been improved to varying degrees in the process of communicating with workers from internship places and interviewing farmers face to face. The ability of students' logical thinking, analyzing and solving problems has also been significantly improved by constantly adjusting the questionnaire content in practice. All students were praised by the internship companies because the problems they have studied the problems from the production practice or were closely related to the lives of residents, and reflected strong pertinence and the practical application value.

\subsubsection{Enhance Professional and Practical Ability of the Teachers}

The cooperation on PTRA for internship in A\&F Economics \& Management was a test to the guidance teachers of thesis and instructors of internship. On the one hand, it required the guidance teachers of thesis to possess certain professional ability and scientific research level, and have a good understanding of the area where the students were going to practice in advance, understand the local production practice and customs, which ensured that students' topics come from the teachers' research or production. The guidance of questionnaire design reflected teachers' strong practical ability, so as to ensure the effectiveness of investigation questions. On the other hand, the instructors of internship also went through the process of "practice-research-learning" in the whole internship, which enhanced their business and practical ability through the cooperative on PTRA together with students.

\subsubsection{Overcome Effectively the Problem of Insufficient Internship Funding}

Internship carried out in the on-campus or off-campus internship bases established through the cooperation of PTRA, on the one hand, greatly reduced the cost of the internship and overcame the problem of insufficient funding. For example, accommodation and training were free of charge for 22 students from cooperation economy in Nehe school of Vocational and Technical Education Center for 1 week. We subsidized students from non-cooperative economy 15 yuan per student for accommodation in farms, which was the discount to us given by the farms. On the other hand, it relieved the pressure of human resources shortage in internship companies through on-the-job internship for part of students and achieved mutual benefit.

\subsubsection{Promote the Reputation of the University and A\&F Economic \& Management}

Practitioners from the companies and farmers from the farms deeply admired teachers from department of A\&F Economic \& Management due to their rigorous, conscientious and pragmatic working attitude and orderly working style in the internship. For example, when we arrived at Yinlonghe Farm, the instructor explained to the manager our work arrangements, tasks and the work we needed them to provide help. The manager was very impressed: I thought that your in- 
ternship was a 2 - 3 day walk-around, but unexpectedly, you would do so for so long, it's true! I must spare no effort to help you to complete the internship task. Students were also praised by practitioners and farmers because of their earnest practice: they repeatedly asked questions and verified the problems that they did not understand, and were deep into the community to help solve the practical problems of farmers. These have promoted the social reputation of Heilongjiang Bayi Agricultural University and A\&F Economic \& Management.

\subsection{Enlightenment of Cooperation on PTRA for Internship in A\&F Economics \& Management}

Of course, there were some problems inevitably in the process of internship because it was just in the stage of exploration and practice for us. For example, the internship effect of some places (e.g. Hongxing Farm and Erlongshan Farm) was not ideal because part of instructors' organization ability was insufficient, which led to little gain for students. However, the inspiration to ensure the effective cooperation on PTRA for internship is as follows. Firstly, it is the basic condition to establish a long-term and stable internship bases on or off the campus. Secondly, business and organizational capabilities of instructors are important factors to mobilize students' enthusiasm in order to ensure the effectiveness of internship. Lastly, it is the guarantee for the effective of cooperation on PTRA in internship to build a systematic cooperative system and establish relevant institutional mechanisms to regulate the implementation.

\section{Conclusion}

Our research suggests that it is necessary to carry out cooperation on PTRA for internship in A\&F Economics \& Management, which may improve professional knowledge level and comprehensive practical ability of students, enhance professional and practical ability of teachers, overcome effectively the problem of insufficient internship funding, promote the reputation of the university and the major from the practice of Heilongjiang Bayi Agricultural University, and provide a reference for other agricultural colleges and universities. However, the paper only takes one agricultural university as an example, which can't represent all types of agricultural universities. Therefore, we will carry out a comparative study of classification through conducting a survey of " 985 ", " 211 " and general agricultural universities in the future.

\section{Conflicts of Interest}

The authors declare no conflicts of interest regarding the publication of this paper.

\section{Funding}

Higher Education Teaching Reform Project in Heilongjiang Province, Research on Cooperation on PTRA in A\&F Economic \& Management (NO. JG2014010922). 


\section{References}

He, P. M. (2011). A\&F Economics and Management Professional Curriculum System Reform Discuss in New Rural Construction. Agriculture of Higher Education, No. 3, 53-55. 